\title{
BUDI DAYA KARANG HIAS MENDUKUNG PERDAGANGAN KARANG HIAS YANG BERKESINAMBUNGAN
}

\author{
Ofri Johan*), Wartono Hadie*, Adang Saputra*), Joni Haryadi*), \\ dan Nurbakti Listyanto")
}

\begin{abstract}
ABSTRAK
Kegiatan budi daya karang hias di Indonesia perlu dilakukan untuk menjamin perdagangannya agar berjalan tanpa merusak keanekaragaman dan kondisi terumbu karang. Budi daya karang hias menggunakan rak berupa meja yang terbuat dari paralon PVC yang dinilai sangat ekonomis dan mudah diaplikasikan masyarakat lokal. Pengamatan pertumbuhan hanya dilakukan pada 1 rak masing-masing jenis karang yang dibudidayakan yaitu Acropora sp., Acropora formosa, Acropora humilis, Acropora millepora, Acropora nobilis, dan Seriatopora hystrix. Kegiatan dilakukan pada dua lokasi yaitu Pulau Simakakang-Mentawai, Sumatera Barat dan Gondol, Bali. Pengamatan dilakukan setiap dua bulan dan penelitian dilaksanakan selama 6 bulan. Hasil pengamatan diperoleh tingkat mortalitas pada lokasi Pulau Simakakang diperoleh 5,56\% dari 36 sampel yang diukur dari 6 jenis karang dan 6 ulangan, pertambahan panjang jenis $A$. formosa $0,64 \mathrm{~cm} /$ bulan, lebih cepat dibandingkan dengan jenis $A$. millepora $0,58 \mathrm{~cm} /$ bulan dan jenis lain. Karang $A$. humilis memiliki laju perambatan pada substrat semen dan batang pengikat yang lebih cepat dari jenis lain. Pada lokasi Gondol, Bali memiliki laju pertambahan panjang karang $A$. millepora lebih cepat $(0,50 \mathrm{~cm} / \mathrm{bulan})$ dibandingkan dengan jenis $A$. tenuis $(0,43 \mathrm{~cm} /$ bulan) dan jenis lain berkisar antara $0,21-0,39 \mathrm{~cm} /$ bulan. Tingkat kematian 3 koloni $(7,1 \%)$ dari total 42 koloni yang disampling.
\end{abstract}

ABSTRACT: Ornamental coral culture to support sustainable coral trade. By: Ofri Johan, Wartono Hadie, Adang Saputra, Joni Haryadi, and Nurbakti Listyanto

The culture of ornamental coral is important to be conducted to guarantee the coral trade can be run well without giving impact to coral reef biodiversities and coral reef condition in Indonesia. This cultured using table using nets as a place which is made from PVC pipe. This method can minimize cost comparing with others materials as well as applicable for coastal community. One table can be placed $12(3 \times 4)$ substrate with a distance among others of $25 \mathrm{~cm}$, then fragmented coral were tied to that substrates. This activity was carried out in two locations that were Simakakang Island, Mentawai, West Sumatera, and Gondol, Bali. The observation of mortality found that the one in Simakakang Island had 5.56\% of 36 fragments of 6 species and of 6 replications, length growth of $A$. formosa was $0.64 \mathrm{~cm} /$ month, more rapid than the one of $\boldsymbol{A}$. millepora $(0,58 \mathrm{~cm} / \mathrm{month})$ and others species. A. humilis had encrusted to cement substrate, it was more rapid than the one in others species. Length growth rate of $\boldsymbol{A}$. millepora in Gondol, Bali was more rapid $(0.50 \mathrm{~cm} /$ month) than A. tenuis $(0.43 \mathrm{~cm} /$ month $)$, and others $(0.21-0.39 \mathrm{~cm} /$ month). The mortality rate was $7.1 \%$ (3 colonies) from 42 colonies.

KEYWORDS: coral culture, ornamental coral, trade, sustainable use

*) Peneliti pada Pusat Riset Perikanan Budidaya, Jakarta 


\section{PENDAHULUAN}

Terumbu karang tumbuh dan hidup sangat baik di perairan dangkal (kurang lebih 20 meter) lautan tropis. Kondisinya saat ini dilaporkan dalam keadaan kritis karena pemanfaatan yang sangat berlebihan. Sama halnya pada ekosistem mangrove dan lamun, karena meningkatnya kegiatan manusia dalam pemanfaatan ekosistem terumbu karang memberikan dampak dan pengaruh yang besar terhadap kerusakan ekosistem tersebut.

Pemanfaatan ekosistem terumbu karang yang dapat merusak kondisi terumbu karang di antaranya adalah penangkapan ikan dengan menggunakan alat yang merusak, penambangan karang untuk bahan bangunan dan pengambilan karang sebagai karang hias. Kegiatan lain yang menyebabkan kerusakan karang secara tidak langsung seperti perkembangan pembangunan di wilayah pesisir dengan mengubah lahan pantai menjadi daerah bangunan atau lahan baru yang dapat menyebabkan sedimentasi. Perairan yang banyak mengandung sedimentasi biasanya ditunjukkan oleh tingkat visibility (jarak pandang di air) yang rendah, kondisi ini akan dapat menyebabkan kematian pada hewan karang.

Kerusakan karang juga dapat disebabkan oleh pengambilan secara langsung untuk karang hias. Kegiatan ini semakin meningkat dengan banyaknya permintaan karang hias tujuan ekspor. Indonesia merupakan negara pengeskpor karang hias terbesar di dunia. Saat ini ada sekitar 20-an eksportir yang aktif melakukan kegiatan perdagangan karang yang berdomisili di Jakarta dan Bali, sehingga timbul kekhawatiran kerusakan karang bertambah kalau pengambilan karang hias masih berlangsung terus dari alam tanpa ada solusi yang baik seperti pangaturan perdagangan karang hias berkelanjutan dan mempelopori produksi karang hias dari hasil budi daya (Johan, 2006).

Melalui kegiatan budi daya karang hias diharapkan dapat membantu masyarakat pesisir dalam pemanfaatan karang yang ramah lingkungan. Nelayan pengumpul karang hias dari alam dapat mengubah cara lama tersebut melalui budi daya, sehingga dapat memberikan keuntungan seperti tidak pergi jauh mencari karang hias dari alam, efisiensi waktu dan biaya karena jarak tempuh yang jauh dan mengurangi risiko kesehatan akibat penggunaan kompresor waktu menyelam yang tidak memenuhi syarat.

Penelitian tentang budi daya karang sudah banyak dilakukan terutama di Pulau Pari Kepulauan Seribu dan beberapa lokasi lain. Penelitian tersebut di antaranya melihat laju pertumbuhan karang pada lokasi berbeda (leeward, windward, dan gobah) dan pada karang yang berbeda ukuran besar fragmennya (Johan, 2001), dan penelitian perbedaan laju pertumbuhan karang pada kedalaman yang berbeda. Penelitian untuk melihat kecocokan metode untuk persediaan induk karang hias masih belum pernah dilakukan.

Tujuan dari kegiatan ini adalah memproduksi induk karang hias berkualitas sebagai persiapan mendapatkan anakan siap ekspor. Dampak dari kegiatan ini diharapkan dapat menyelamatkan keanekaragaman karang dan dapat membuka lapangan kerja baru di sektor perikanan.

\section{METODE PENELITIAN}

\section{Waktu dan Lokasi Kegiatan}

Kegiatan penelitian di mulai sejak Juni sampai Desember 2006. Kegiatan dilakukan pada 2 lokasi yaitu Gondol, Kabupaten Buleleng, Bali, dan Tua Pejat Kabupaten Mentawai, Sumatera Barat. Lokasi pertama berada di lokasi Balai Besar Riset Perikanan Budidaya Laut-Gondol dan lokasi kedua di Mentawai mengikutsertakan Dinas Kelautan dan Perikanan Kabupaten Mentawai dalam kegiatan tersebut.

\section{Teknis Pelaksanaan}

\section{Persiapan}

Survai awal dilakukan untuk mendapatkan informasi penting yang berkaitan dengan teknologi budi daya karang hias. Pada survai awal juga ditetapkan lokasi yang sesuai sebagai tempat budi daya karang hias. Persyaratan utama tempat budi daya karang hias adalah kejernihan perairan (visibility) harus lebih baik, kedalaman antara $3-5 \mathrm{~m}$, arus tidak terlalu kuat sehingga tidak membuat rak terbalik, dan lokasi tidak pada jalur pelayaran dan lokasi penangkapan ikan sehingga diharapkan lokasi dapat terjaga dari faktorfaktor pengrusakan.

Tahap berikut yang perlu dipersiapkan yaitu pengadaan substrat, rak substrat, dan 

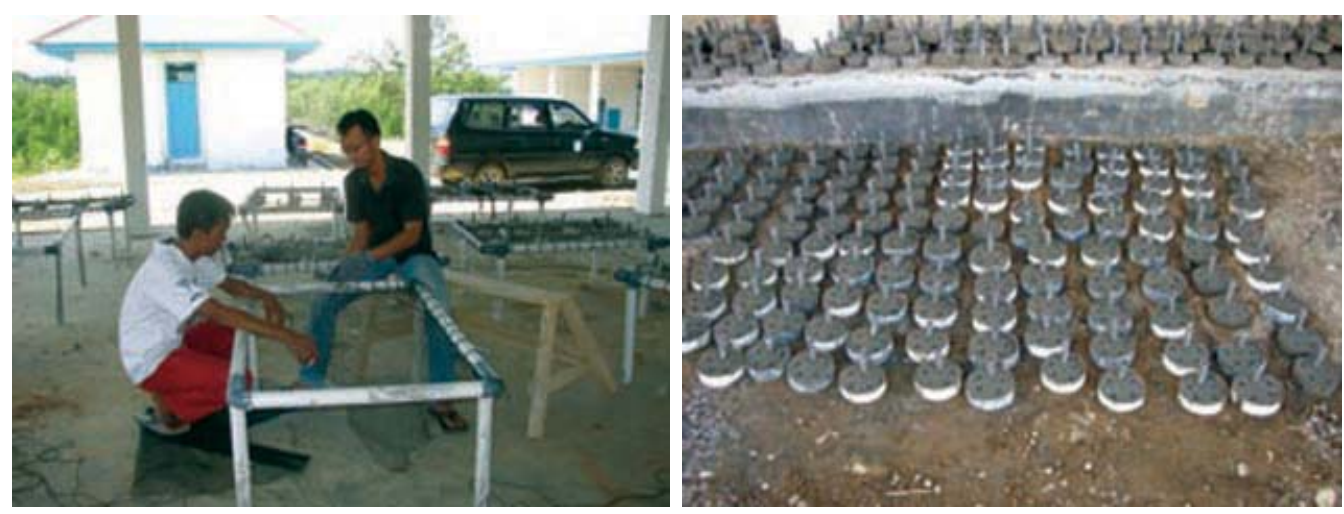

Gambar 1. Pembuatan rak paralon PVC dan substrat buatan yang digunakan pada kegiatan budi daya karang hias. Rak paralon (kiri) berukuran (panjang $x$ lebar $x$ tinggi) $80 \mathrm{~cm} \times 100 \mathrm{~cm} \times 40 \mathrm{~cm}$

Figure 1. Preparation of PVC frame and artificial substrate for ornamental coral propagation. PVC frame (left) size length, widht and height are $80 \mathrm{~cm} \times 100 \mathrm{~cm} \times 40 \mathrm{~cm}$

peralatan selam serta alat dokumentasi (Gambar 1). Kegiatan berikut adalah pengikatan jaring ke rak paralon dan pengikatan substrat buatan ke jaring. Substrat diatur sedemikian rupa dengan jarak antar substrat sekitar $25 \mathrm{~cm}$, sehingga dalam satu rak terdapat 14 buah substrat.

Rak paralon yang sudah pasang substrat ditempatkan di lokasi tempat budi daya pada kedalaman 3-5 meter dengan posisi paralel dengan garis pantai (Gambar 2). Penyusunan rak ini sangat membantu dalam pencatatan data saat monitoring berikutnya, karena di dalam air jarak pandang seorang penyelam terbatas bila dibandingkan dengan kondisi di darat.

\section{Pelaksanaan}

Pada kegiatan pelaksanaan perlu dilakukan pencarian induk, pemotongan karang menjadi fragmen, pengikatan fragmen karang ke

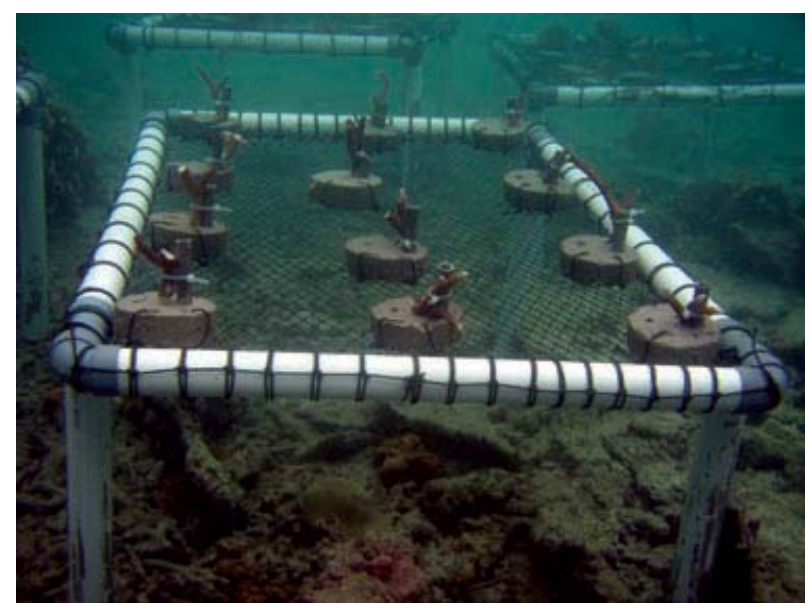

Gambar 2. Rak paralon PVC yang sudah dipasang jaring, substrat semen dan fragmen karang hias

Figure 2. PVC frame has attached a nets, cement artificial substrate, and ornamental coral fragment 
substrat, pencatatan data pertumbuhan dan data parameter kualitas perairan.

Pencarian induk karang dilakukan sekitar lokasi penelitian pada jenis karang yang cepat tumbuh (karang bercabang) sehingga tidak perlu transportasi yang jauh karena transportasi dapat menyebabkan karang menjadi stres dan mati. Pengambilan induk diusahakan tidak secara utuh tapi maksimal dua pertiga dari ukuran induk yang boleh diambil. Ukuran sepertiga yang tinggal diharapkan dapat pulih kembali sehingga tidak terjadi kerusakan kondisi karang di lokasi pengambilan.

Alat yang digunakan untuk pemotongan saat pengambilan adalah pahat besi dan palu, prosesnya diusahakan se-efektif mungkin sehingga tidak merusak koloni induk secara keseluruhan (Gambar 3). Kemampuan penyelam juga sangat menentukan keberhasilan pemotongan tanpa merusak koloni induk, apabila kemampuan bouyancy penyelam belum stabil akan menyebabkan kerusakkan koloni induk saat pemotongan.

Karang untuk bibit dipotong menjadi ukuran antara $5-10 \mathrm{~cm}$ dan ikatkan pada substrat dengan bantuan tali pengikat dari bahan plastik. Satu rak bisa untuk $9-12$ substrat karang. Karang budi daya dipersiapkan untuk kelompok induk yang bibitnya diambil dari alam. Kelompok kedua nanti merupakan hasil biakan dari kelompok pertama dan hasil budi daya yang boleh dimanfaatkan tersebut adalah setelah biakan dari induk kedua.
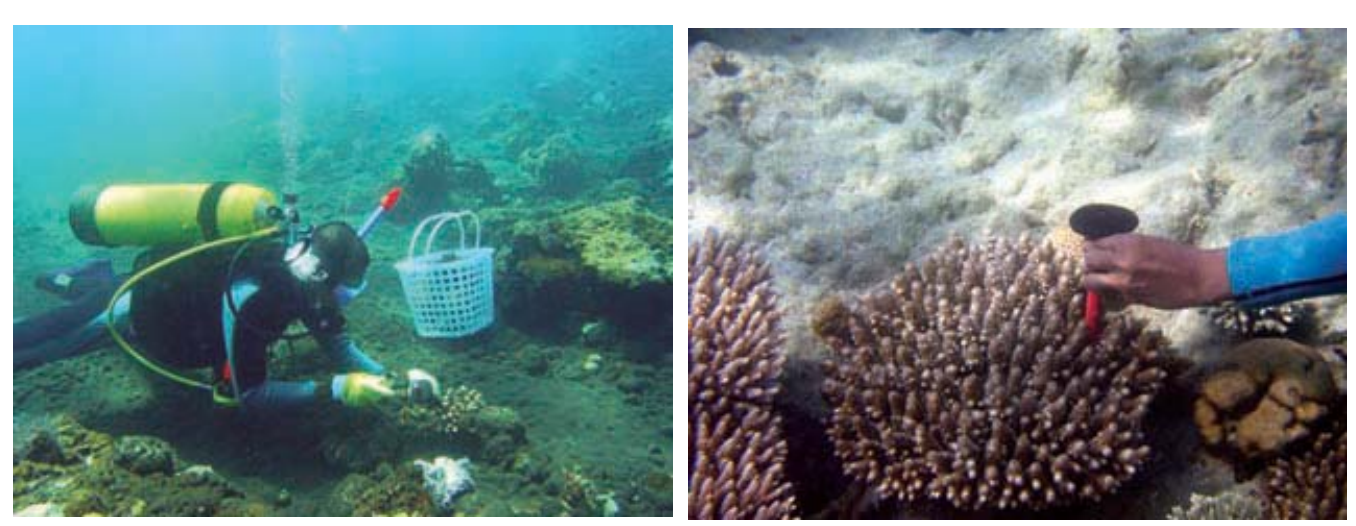

Gambar 3. Pengambilan bibit karang sebagai fragmen untuk di budi dayakan

Figure 3. Collecting a broodstock for coral fragment in ornamental coral propagation

\section{Monitoring}

\section{Pertumbuhan dan sintasan}

Pengukuran pertumbuhan karang didasarkan pada pertumbuhan panjang mutlak bagi karang bercabang dan diameter koloni pada jenis Seriatopora hystrix yang dilakukan setiap 2 bulan dengan menggunakan jangka sorong (caliper). Pengukuran pertumbuhan hanya dilakukan pada perwakilan individu yang telah ditentukan dalam satu rak setiap jenis yang dibudidayakan. Tingkat sintasan dihitung berdasarkan jumlah individu yang berhasil hidup dari perwakilan koloni yang diukur setiap bulan selama pengamatan dibandingkan dengan total koloni yang dibudidayakan.

Posisi sampel substrat karang untuk pengambilan data pertumbuhan karang:

Dalam satu rak terdiri atas 12 substrat namun yang diambil data pertumbuhannya hanya setengahnya (Gambar 4). Perhitungan sintasan dilakukan pada semua fragmen di setiap rak yang ditempatkan di lokasi tersebut.

\section{Pengukuran peubah lingkungan}

Untuk melihat hubungan antara pertumbuhan dengan peubah lingkungan dilakukan pengukuran beberapa peubah lingkungan fisik dan kimia, meliputi suhu, salinitas, dan $\mathrm{pH}$, yang dilakukan secara in situ di sekitar hewan uji; serta fosfat, dan nitrat yang dianalisis di laboratorium. Pengukuran peubah tersebut dilakukan setiap bulan selama penelitian. 
2

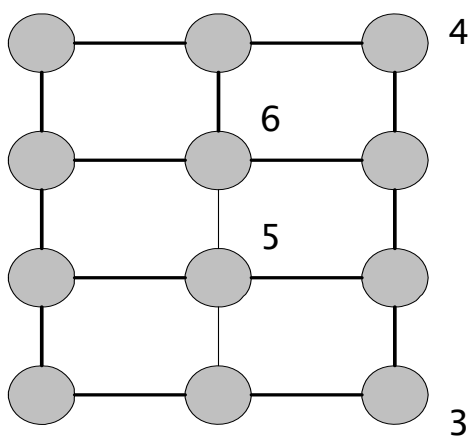

Keterangan (Note):

Gambar tampak atas

Figure from upside view

1--6: Urutan penghitungan substrat Counting substrate step

: Pipa paralon (PVC pipe)

: Substrat (Substrate)

Gambar 4. Disain posisi fragmen karang yang dijadikan sampel untuk data pertumbuhan

Figure 4. Design of coral fragment position for growth rate data sampling

\section{Analisis Data}

Untuk mengetahui sintasan hewan uji dihitung menurut Stiling (1999):

$$
\mathrm{S}=\frac{\mathrm{N}_{\mathrm{o}}}{\mathrm{N}_{\mathrm{t}}} \times 100 \%
$$

di mana:

$\mathrm{S}=$ sintasan (\%)

$\mathrm{Nt}=$ jumlah individu akhir

No $=$ jumlah individu awal

Untuk mengetahui pertumbuhan panjang mutlak dan diameter masing-masing jenis karang dihitung berdasarkan formula Affandi \& Tang (2001):

$$
a=L t-L o
$$

di mana:

$\mathrm{a}=$ pertumbuhan diameter ind $(\mathrm{mm})$

Lt $=$ diameter ind $(\mathrm{mm})$ pada waktu ke-i

Lo $=$ diameter ind $(\mathrm{mm})$ pada waktu ke-0

Sintasan dan respon pertumbuhan mutlak antara metode transplantasi pada masingmasing lokasi dianalisis secara deskriptif.

\section{HASIL DAN BAHASAN}

\section{Lokasi Pulau Simakakang, Mentawai}

Berdasarkan pengamatan selama penelitian terlihat bahwa karang jenis $A$. formosa memiliki laju pertumbuhan panjang $0,64 \mathrm{~cm} /$ bulan (Tabel 1) lebih cepat dibandingkan dengan jenis lain. Kemudian diikuti oleh Acropora millepora $0,58 \mathrm{~cm} /$ bulan.

Tabel 1. Rata-rata pertumbuhan karang hias di Pulau Simakakang, Tua Pejat Mentawai selama penelitian

Table 1. Growth rate of ornamental coral on Simakakang Island, Tua Pejat Mentawai during research

\begin{tabular}{clcccc}
\hline \multirow{2}{*}{$\begin{array}{c}\text { Kode rak } \\
\text { Frame code }\end{array}$} & $\begin{array}{c}\text { Jenis karang } \\
\text { Coral species }\end{array}$ & $\begin{array}{c}\text { Pert umbuhan panjang (cm/bulan) } \\
\text { Growth rate (cm/month) }\end{array}$ & \begin{tabular}{c} 
Rataan \\
(cm/bulan) \\
Average \\
\cline { 3 - 5 }
\end{tabular} & $\begin{array}{c}\text { September November } \\
\text { Sept ember }\end{array}$ \\
\hline A & Acropembora sp. & 0.20 & 0.72 & 0.70 & 0.54 \\
B & Acropora formosa & 0.55 & 0.60 & 0.77 & 0.64 \\
C & Acropora humilis & 0.17 & 0.87 & 0.40 & 0.48 \\
D & Seriatopora hystrix & 0.12 & 0.08 & 0.53 & 0.24 \\
E & Acropora millepora & 0.22 & 0.63 & 0.88 & 0.58 \\
F & Acropora nobilis & 0.15 & 0.90 & 0.57 & 0.54 \\
\hline
\end{tabular}


A. formosa memiliki bentuk pertumbuhan arborescent artinya pertumbuhan kearah panjang vertikal, berbeda dengan A. millepora yang lebih cenderung melebar seperti meja. $A$. humilis memiliki bentuk pertumbuhan digitata di mana bentuk percabangannya lebih besar dan pendek. Namun A. humilis ini memiliki laju perambatan pada substrat semen dan batang pengikat (terbuat dari paralon) lebih cepat, bahkan pada waktu tertentu batang pengikat bisa diselimuti oleh pertumbuhan karang. Kondisi ini terlihat pada pengamatan transplantasi karang yang sudah berlangsung cukup lama di Pulau Pari, Kepulauan Seribu di mana penempelan pada substrat sudah berkembang dengan baik, bahkan substrat dan batang pengikat tidak kelihatan lagi karena sudah diselimuti oleh pertumbuhan karang tersebut (Johan, 2005).

Sebagian besar karang berhasil hidup dan menempel pada substrat. Berdasarkan pengamatan selama penelitian diperoleh tingkat mortalitas dari semua sampel yang dibudidayakan sebanyak 77 koloni atau $26,74 \%$. Namun dilihat dari jumlah sampel yang diukur pertumbuhannya yaitu sebanyak 36 sampel yang terdiri dari 6 jenis karang dan masing-masing jenis dilakukan ulangan sebanyak 6 kali, diperoleh hanya 2 fragmen atau $5,56 \%$ yang mengalami kematian. Tingkat kematian ini cukup rendah, sama halnya dengan metode rak yang terbuat dengan besi di Pulau Pari, di mana perlakuan jenis karang $A$. formosa, A. acuminata, dan $A$. donei dengan ulangan masing-masing 12 fragmen diperoleh kematian pada akhir penelitian setelah 6 bulan hanya 2 koloni (Johan, 2001).

Perairan di Pulau Simakakang, Tua Pejat Mentawai memiliki kualitas perairan yang dapat mendukung pertumbuhan karang dengan baik. $\mathrm{Hal}$ ini terlihat bahwa perairan cukup jernih, perairan cukup terlindung sehingga tidak berpengaruh meskipun adanya perubahan musim Barat dan musim Timur yang biasanya berombak cukup besar. Penempel biota pengotor pada substrat tidak begitu banyak dibandingan dengan lokasi di Bali, hanya ditemukan turf algae yang melekat dan jaringnya juga lebih bersih.

Penempelan pada substrat sudah terjadi sebagian fragmen pada bulan kedua. Karang yang memiliki perambatan pada substrat yang lebih cepat terjadi pada jenis karang $A$. millepora dan $A$. humilis. Selain karena jenis karang yang memiliki laju perambatan yang lebih cepat, kecepatan perambatan juga ditentukan oleh kekokohan pengikatan fargmen karang ke substrat. Karang akan lebih cepat merambat ke substrat apabila pengikatannya lebih kokoh sehingga tidak goyang karena adanya arus dan ombak (Gambar 5).

Parameter kualitas air di lokasi penelitian sangat mendukung pertumbuhan karang, berdasarkan data di lapangan diperoleh ratarata masing-masing parameter selama penelitian yaitu arus $8,71 \mathrm{~m} /$ detik; suhu $27^{\circ} \mathrm{C}$; salinitas $32,7 \%$; Nitrat $0,062 \mathrm{mg} / \mathrm{L}$; dan fosfat $0,033 \mathrm{mg} / \mathrm{L}$.

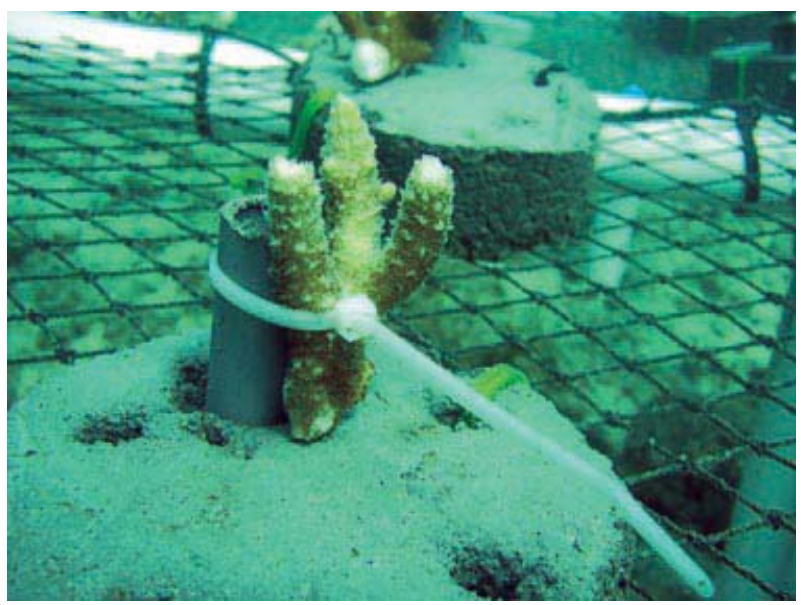

Gambar 5. Pengikatan fragmen karang menggunakan tali ties plastik

Figure 5. Coral fragment tied by plastic tyes 


\section{Lokasi Gondol, Bali}

Pada lokasi Gondol, Bali terlihat bahwa karang jenis $A$. millepora memiliki laju pertumbuhan lebih cepat $(0,50 \mathrm{~cm} /$ bulan $)$ dibandingkan dengan jenis lain, kemudian diikuti oleh jenis karang $A$. tenuis $(0,43 \mathrm{~cm} /$ bln). Sementara jenis lain berkisar antara $0,21-0,39 \mathrm{~cm} /$ bulan (Tabel 2).

Substrat buatan banyak ditumbuhi biota pengganggu dan juga banyak endapan sedimentasi pada jaring sehingga sangat perlu dilakukan pembersihan biota tersebut. Kondisi tersebut apabila tidak dibersihkan akan dapat mengganggu perambatan karang pada substrat dan juga akan mengganggu pertumbuhan (Gambar 6).

Karang yang dibudidayakan berasal pada kedalaman yang sama dengan sumber induk untuk meminimalkan tingkat kematian. Umumnya karang yang diujicobakan merupakan jenis karang yang berada pada kedalaman dangkal seperti salah satu jenis dari kelompok pocilloporid yaitu jenis Pocillopora damicornis (Fan et al., 2002).

Pada Tabel 3 terlihat bahwa jenis karang pada metode rangkaian kawat K3 ( $A$. tenuis) memiliki kecepatan pertumbuhan rata-rata perbulan yang lebih tinggi $(0,70 \mathrm{~cm} /$ bulan $)$

Tabel 2. Laju pertumbuhan karang selama penelitian menggunakan rak paralon PVC

Table 2. Coral growth rate using PVC frame during research

\begin{tabular}{|c|c|c|c|c|c|}
\hline \multirow{2}{*}{$\begin{array}{l}\text { Kode rak } \\
\text { Frame code }\end{array}$} & \multirow{2}{*}{$\begin{array}{l}\text { Jenis karang } \\
\text { Coral species }\end{array}$} & \multicolumn{3}{|c|}{$\begin{array}{l}\text { Pert umbuhan panjang }(\mathrm{cm} / \mathrm{bulan}) \\
\text { Growth rate }(\mathrm{cm} / \mathrm{month})\end{array}$} & \multirow{2}{*}{$\begin{array}{c}\text { Rataan } \\
\text { (cm/bulan) } \\
\text { Average } \\
\text { (cm/month) }\end{array}$} \\
\hline & & $\begin{array}{l}\text { Sept ember } \\
\text { September }\end{array}$ & $\begin{array}{l}\text { November } \\
\text { Novem ber }\end{array}$ & $\begin{array}{l}\text { Desember } \\
\text { December }\end{array}$ & \\
\hline $\mathrm{Al}$ & Acropora millepora & 0.15 & 0.42 & 0.93 & 0.50 \\
\hline A10 & Montipora porites & 0.15 & 0.18 & 0.28 & 0.21 \\
\hline B 1 & Acropora tenuis & 0.12 & 0.43 & 0.75 & 0.43 \\
\hline B6 & Acropora humilis & 0.13 & 0.20 & 0.38 & 0.24 \\
\hline B 13 & Pocillopora damicornis & 0.13 & 0.30 & 0.25 & 0.23 \\
\hline B 18 & Porites negrescen & 0.13 & 0.17 & 0.35 & 0.22 \\
\hline B 19 & Acropora sp. & 0.13 & 0.65 & 0.40 & 0.39 \\
\hline
\end{tabular}
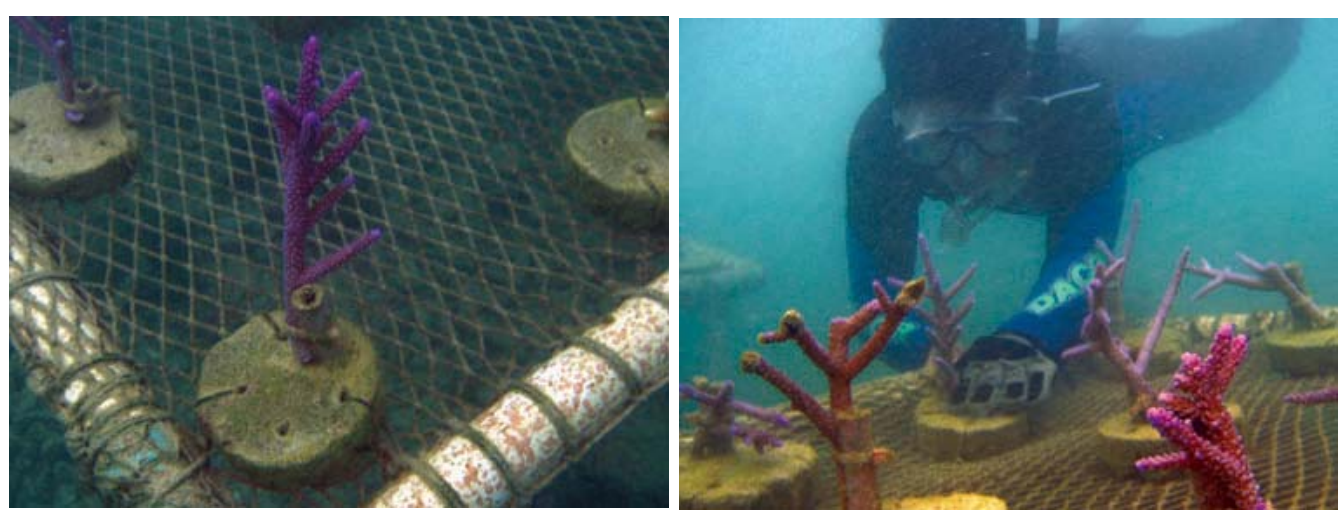

Gambar 6. Kondisi karang setelah 2 minggu. Pembersihan substrat dan jaring (kanan) harus dilakukan untuk menghindari kompetisi dengan pertumbuhan alga dan biota penganggu lainnya

Figure 6. Coral propagation after 2 week. The substrate and nets should be cleaned (right) to avoid algae and other organism space competition 
dibandingkan dengan jenis lain. Sementara laju pertumbuhan jenis karang yang lain tidak jauh berbeda yaitu antara $0,27-0,35 \mathrm{~cm} /$ bulan

Setelah bibit berumur \pm 2 bulan, dilakukan pengukuran bibit karang hias dan mengamati penempelan bibit pada substrat. Dari pengamatan yang dilakukan, terlihat bahwa bibit telah menempel pada substrat (Gambar 7).

Pada perairan Gondol tidak dipengaruhi oleh arus selat, tapi pada musim timur (sekitar bulan Agustus-Oktober) ada angin dan ombak yang cukup kuat, namun sebaliknya pada musim barat lokasi tersebut akan terlindung. Pada pengamatan selama penelitian tidak ditemukan kerusakan dan kondisi rak yang terbalik.
Tingkat kematian selama penelitian pada metode rak paralon PVC ditemukan 3 koloni yang mati $(7,11 \%)$ dari total 42 koloni yang disampling pengambilan data pertumbuhan dan tingkat mortalitasnya. Tingkat kematian ini cukup kecil sehingga faktor lingkungan masih mendukung bagi pertumbuhan karang di lokasi tersebut.

Berdasarkan data kualitas perairan lokasi tersebut masih berada pada daerah yang cocok bagi pertumbuhan karang, di mana selama penelitian diperoleh data rata-rata yaitu suhu $26,9^{\circ} \mathrm{C}$; salinitas $32,7 \%$; fosfat $0,05 \mathrm{mg} /$ $\mathrm{L}$; dan nitrat $0,22 \mathrm{mg} / \mathrm{L}$.

\section{Bahasan}

Perairan di Pulau Simakakang berada pada suatu lokasi yang di sekitarnya banyak pulau

Tabel 3. Laju pertumbuhan karang selama penelitian menggunakan rangkaian kawat antar substrat

Table 3. Coral growth rate during research on wire frame between substrate

\begin{tabular}{clcccc}
\hline \multirow{2}{*}{$\begin{array}{c}\text { Kode rak } \\
\text { Frame } \\
\text { code }\end{array}$} & $\begin{array}{c}\text { Jenis karang } \\
\text { Coral species }\end{array}$ & \multicolumn{2}{c}{$\begin{array}{c}\text { Pert umbuhan panjang (cm/bulan) } \\
\text { Growth rate (cm/month) }\end{array}$} & $\begin{array}{c}\text { Rataan } \\
\text { (cm/bulan) } \\
\text { Average }\end{array}$ \\
\cline { 3 - 6 } & & $\begin{array}{c}\text { September } \\
\text { September }\end{array}$ & $\begin{array}{c}\text { November } \\
\text { November }\end{array}$ & $\begin{array}{c}\text { Desember } \\
\text { December }\end{array}$ & $\begin{array}{c}\text { Avm/month) } \\
\text { (cm } / \text { month }\end{array}$ \\
\hline J7 & Acropora millepora & 0.22 & 0.48 & 0.34 & 0.35 \\
K1 & Acropora humilis & 0.20 & 0.26 & 0.48 & 0.31 \\
K3 & Acropora tenuis & 0.16 & 1.52 & 0.42 & 0.70 \\
K5 & Porites negrescen & 0.20 & 0.36 & 0.24 & 0.27 \\
L1 & Pocillopora damicornis & 0.24 & 0.34 & 0.28 & 0.29 \\
\hline
\end{tabular}
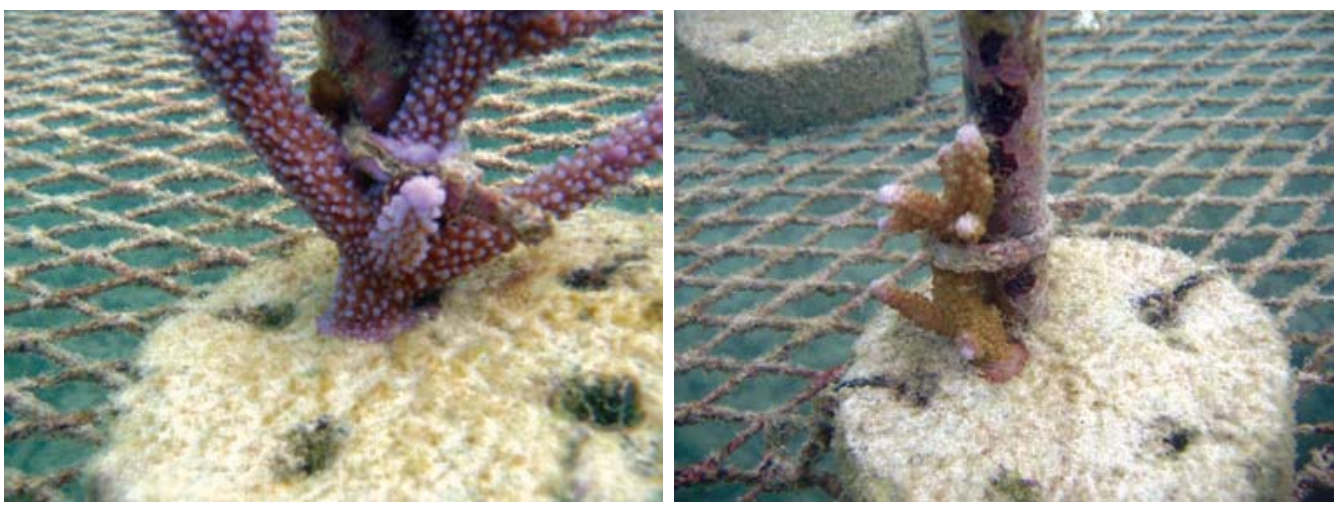

Gambar 7. Kondisi karang setelah 2 bulan. Terlihat karang sudah mulai menempel pada substrat

Figure 7. Coral propagation after 2 month. Coral encrusted to artificial substrate 
sekitar 4 buah. Di antara pulau dibatasi dengan suatu perairan yang memiliki arus yang lebih kuat. Kondisi ini sangat menguntungkan lokasi dimana dilakukan budi daya karang hias, meskipun agak terlindung namun perairan sekitarnya memiliki sirkulasi dan pergantian air cukup tinggi karena adanya arus tersebut.

Sirkulasi air (arus) sangat penting dalam proses fisika karang, membantu proses fotosintesis dengan simbiosis dengan alga dan meningkatkan jaringan karang dalam pernapasan. Arus juga dapat memberikan dampak positif dengan dibawanya partikelpartikel termasuk zooplankton dan material lain yang dibutuhkan oleh karang, nutrien terlarut dapat diambil oleh karang dan sedimen yang menutupi permukaan karang dapat hilang/lepas karena adanya pergerakan air (Sebens et al., 2003). Kondisi tersebut dapat menyebabkan karang dapat tumbuh lebih cepat karena adanya arus yang mendukung.

Karang batu ataupun karang lunak memiliki kemampuan untuk berkembang biak secara seksual yang dapat dilihat di perairan terjadinya rekruitmen koloni baru. Rekruitmen karang baru dibatasi oleh banyaknya jumlah larva karena kemungkinan berhasil menempel hingga dewasa sangatlah kecil, apalagi ada faktor penganggu yang menghambat terjadinya penempelan karang seperti tumbuhnya alga pada substrat dan endapan sedimen pada substrat ataupun di jaring.

Budi daya karang lunak sedikit lebih susah dibandingkan dengan budi daya karang keras kalau tanpa merusak jaringan tubuh seperti pada metode ini melalui penusukan tubuh dengan pengikatan dengan tali. Demikian juga pengikatan fragmen dapat membuat tubuh mengkerut dan mengecil dari ukuran normal sebelum dilakukan pengikatan, sehingga kondisi ini dapat menyebabkan stress dan bahkan dapat menyebabkan kematian (Hudson \& Goodwin, 1997).

Pembersihan substrat karang dan jaring pada kedua lokasi propagasi sangat perlu dilakukan karena pada kedua media tersebut banyak ditemukan endapan sedimen, alga, dan sampah. Pertumbuhan karang akan terganggu apabila substrat ditumbuhi oleh turf algae atau coralline algae. Kondisi tersebut akan lebih sulit apabila jenis alga tersebut mengandung unsur bioaktif yang dapat membunuh biota karang (Hudson \& Goodwin, 1997; Jompa \& McCook, 1999).

\section{KESIMPULAN}

Induk karang hias untuk tujuan karang hias sudah berhasil dibudidayakan menggunakan metode substrat buatan yang ditempatkan pada rak paralon PVC berukuran lebar, panjang, dan tinggi $80 \mathrm{~cm} \times 100 \mathrm{~cm} \times 40 \mathrm{~cm}$ dengan permukaan diberi jaring sebagai tempat pengikatan substrat. Laju pertumbuhan berkisar antara 0,21-0,64 cm/bulan, laju pertumbuhan tertinggi terjadi pada karang Acropora formosa di Pulau Simakakang, Mentawai.

Tingkat kematian tergolong rendah pada metode rak paralon PVC di Pulau Simakakang 5,55\% dan Gondol 7,14\%.

Kegiatan sebaiknya dilanjutkan pada tahap berikutnya dengan memotong induk karang yang sudah berhasil dibudidayakan untuk mendapatkan anakan pada substrat yang lebih spesifik dan cocok untuk perdagangan, biasanya lebih ringan dan artistik.

\section{UCAPAN TERIMA KASIH}

Penulis mengucapkan terima kasih atas bantuan dari Kepala Dinas Perikanan Kabupaten Kepulauan Mentawai yang telah menyediakan staf dalam mendampingi dan staf peneliti Balai Besar Riset Perikanan Budidaya Laut Gondol, sehingga penelitian ini dapat terlaksana dengan baik.

\section{DAFTAR PUSTAKA}

Affandi, R. dan U.M. Tang. 2001. Fisiologi Hewan Air. Unri Press, Riau. 217 pp.

Fan Tung-Yung, Li Jan-Jung, Le Sheng-Xian, and Fang Lee-Shing. 2002. Lunar Periodicity of Larval Release by Pocilloporid Corals in Southern Taiwan. Zoological Studies. 41 (3): 288-294.

Hudson, J.H. and W.B. Goodwin. 1997. Restoration and growth rate hurricane damaged pillar coral (Dendrogyra cylindrus) in the Key Largo National Marine Sanctuary, Florida. Proceedings of the Eighth International Coral Reef Symposium, Panama, June, 1996. p. 567-570.

Johan, O. 2001 . Tingkat Keberhasilan Transplantasi Karang Batu Pada Lokasi Berbeda Di Gugusan Pulau Pari Kepulauan Seribu Jakarta. Tesis. Program Pascasarjana, Institut Pertanian Bogor. 89 pp.

Johan, O. 2005. Transplantasi Karang 
Menggunakan Metode yang Efektif, Efisien dan Ekonomis. Prosiding Seminar Nasional Tahunan Hasil Penelitian Perikanan dan Kelautan UGM. MSP. p.147-146.

Johan, O. 2006. Mengenal Karang Hias Bernilai Ekonomis Penting di Indonesia. Warta Perikanan Edisi Budi Daya. 1(3): 87-90.

Jompa, J. and L.J. McCook 1999. The impact of Sargassum canopy on the recovery of bleached corals on inshore reefs. Preliminary report to the Great Barrier Reef Marine Park Authority, Townsville. 11 pp.
Sebens, K.P., B. Helmuth, E. Carrington, and B. Agius. 2003. Effects of water flow on growth and energetic of the scleractinian coral Agaricia Tenuifolia in Belize. Coral Reefs. 22: 35-47.

Stiling, P. 1999. Ecology: Theories and Applications. Prentice-Hall, Upper Saddle River, New Jersey. 596 pp 